\title{
CHRONOLOGICAL OUTLINE
}

(Italics indicate major historical events in which Lafayette did not participate.)

\section{7}

September 6. Lafayette born at Chavaniac, in Auvergne.

1759

August 1. Father killed at the Battle of Minden. 1760

April 5. Birth of sister, Marie-Louise-Jacqueline, who died three months later. 1763

February Io. Treaty of Paris: France, defeated in Seven Years' War, gives up all claims in North America. 1768

Lafayette moves to Paris; enters Collège du Plessis.

$177^{\circ}$

April 3. Mother dies.

May. Inherits a large fortune from his grandfather. 1771

April 9. Becomes a sous-lieutenant in the King's Musketeers.

1773

February ${ }_{15}$. Moves to the Hôtel de Noailles, the residence of the Duc d'Ayen at Versailles, as a protégé of the duc.

April 7 . Becomes a lieutenant in the Noailles Dragoons. 1774

April 11. Marries Adrienne de Noailles.

May 19. Becomes a captain in the Noailles Dragoons.

Summer. On maneuvers with his regiment at Metz, under the command of the Comte de Broglie.

1775

Becomes a Freemason.

Summer. Stationed at Metz; at a dinner given by Broglie, hears the Duke of Gloucester speak of the American revolt.

December 15 . Birth of daughter, Henriette de Lafayette. 
1776

June 11. Placed on reserve status.

December 7. Signs agreement to serve as a major general in the American army.

1777

February. Buys La Victoire, in which he plans to carry a party of French officers to America.

February 21-ca. March 9. Visits London.

ca. March 13. Returns secretly to Paris.

March 16-19. Travels to Bordeaux with Kalb.

March 25-28. La Victoire sails from Bordeaux to Pasajes, Spain.

March 31-April 3. Receives royal order to join the Duc d'Ayen at Marseilles and leaves Pasajes for Bordeaux.

April 3-12. Requests permission to go to America. Request denied. Pretends to proceed to Bordeaux.

April 2o. Sails from Pasajes on La Victoire.

June 13. Arrives at North Island, South Carolina.

July 1. Birth of daughter Anastasie in Paris.

July 27. Arrives at Philadelphia; reports to Congress.

July 31. Appointed major general, but without command; invited to join Washington's military "family."

September 11. Wounded in the leg at the Battle of Brandywine.

September 21-October 18. At army hospital at Moravian settlement in Bethlehem, Pennsylvania.

September 27-3o. Congress assembles at Lancaster and then moves to York, Pennsylvania. British occupy Philadelphia.

October 3. Death of daughter Henriette in Paris.

October I 7. Burgoyne surrenders to Gates.

November 25. Lafayette commands at a skirmish at Gloucester, New Jersey.

December 1. Receives command of a division.

1778

January 23. Selected by Congress to lead an "irruption" into Canada.

February 6. Franco-American treaties of alliance and commerce signed in Paris.

February 7-1 7. Lafayette travels to Albany, New York.

February 19. Decides the Canadian expedition is not feasible. Assumes command at Albany.

March 31. Leaves Albany to resume command of his division at Valley Forge.

April I 2. Carlisle Peace Commission appointed.

May 2. Simeon Deane brings the Franco-American treaties to Congress.

May 4. Congress ratifies the treaties.

May 6. Army celebrates the French alliance at Valley Forge.

May I 8. Mischianza in Philadelphia.

May 18. Lafayette given command of an independent detachment to obtain intelligence of British movements and interrupt British communications.

May 2o. Retreat from Barren Hill.

June 17. Attends council of war to determine campaign plans, in response to expected British evacuation of Philadelphia. 
June I 7. Congress rejects proposals of British peace commissioners.

June I 8. British evacuate Philadelphia.

June 28. Battle of Monmouth.

July 4. Court-martial suspends General Lee.

July I I. D'Estaing arrives off New York.

July 1 2. Gérard arrives in Philadelphia.

July 22. Lafayette appointed to the command of a detachment of the main army ordered to Rhode Island to serve under Sullivan.

July 23-August 4 . On the road to Providence.

August 4. Visits d'Estaing's flagship, Le Languedoc.

August 5. In Providence.

August 5. Suffren sails up Sakonnet Passage; British run their ships aground and destroy them.

August 6. Gérard received by Congress.

August 8. D'Estaing sails up the middle passage.

August 8-9. British evacuate works on northern end of Rhode Island; Sullivan crosses ahead of schedule to occupy them.

August 9. British fleet under Howe seen appearing off Newport. American council of war decides to remain in Rhode Island.

August ro. D'Estaing gives chase to Howe's fleet.

August I I-I 3. Hurricane batters d'Estaing's fleet.

August 14. Howe withdraws to New York.

August 20. D'Estaing reappears at Rhode Island.

August 21. Lafayette visits d'Estaing on board Le Languedoc. D'Estaing sails for Boston.

August 23. Sullivan solicits opinion of general officers on the question of retreating.

August 24. General orders deprecate French departure; Hancock leaves for Boston.

August 27. D'Estaing arrives in Boston.

August 27-28. Lafayette goes to Boston.

August 28-29. Americans begin withdrawal from Rhode Island; British under Pigot pursue, but Americans repulse attacks.

August 30-31. Lafayette assists in successful evacuation of Rhode Island.

ca. September 1. Establishes his quarters in Bristol.

September I. Clinton arrives at Newport with reinforcement of 5,ooo troops.

September 5. British fleet sighted off Sakonnet Passage.

September 5-8. Grey raids towns on coasts of Massachusetts and Martha's Vineyard.

September 8. Saint-Sauveur mortally wounded in a riot in Boston.

September 14. Franklin elected minister plenipotentiary to France.

September 21 . At Warren, Rhode Island.

September 27. Jay named minister to Spain; Adams appointed to negotiate peace.

September 28-October 1. In Boston.

September 28. Lafayette requests leave from Sullivan to visit headquarters.

October 5. At Fishkill. Challenges Carlisle to a duel.

October 13. Requests leave from Congress to return to France. 
October 21. Congress authorizes leave and votes to present a sword to Lafayette.

October 27. Leaves Philadelphia for Boston.

November. Ill at Fishkill.

November 4. D'Estaing sails from Boston for the West Indies.

ca. December 11. Lafayette arrives in Boston.

1779

January 2. Congress lays aside plans for invading Canada.

January 5 . On board the Alliance in Boston Harbor.

January 11. The Alliance sails; Lafayette carries Franklin's commission as minister plenipotentiary.

January. The French under Lauzun capture Senegal.

February 3. Pennsylvania Executive Council charges Arnold with misconduct in his government of Philadelphia.

February 6. The Alliance reaches Brest.

February 12. Lafayette arrives at Versailles; confers with Maurepas.

February 12-19. Under house arrest in Paris.

March 3. Named lieutenant-commander of the King's Dragoons with the rank of mestre de camp.

March 1 o. Convention of Ainalikawak resolves disputes between Turkey and Russia.

March 14-31. Lafayette discusses plans for a raid on Irish and English coasts. An expedition under Lafayette and Jones decided upon.

April I 2. Aranjuez Convention confirms the alliance of France and Spain.

April zo-May 1. The Prince de Nassau-Siegen leads expedition against the Isle of Jersey.

May 13. Peace of Teschen concludes War of the Bavarian Succession.

ca. May 17-June. Lafayette urges that he be considered in the new plans being made for a joint French-Spanish expedition against England.

May 22. Lafayette-Jones expedition abandoned; ordered to take command of the King's Regiment of Dragoons.

May 23. Urges ministry to consider an invasion of Ireland.

May-November. Sullivan's expedition against the Indians.

June I. British take Stony Point and Fort Lafayette.

June 4. D'Orvilliers sails from Brest.

June 13. Lafayette ordered to Versailles to meet with Vaux, who will command the troops in Normandy; made aide-maréchal-général-des-logis under Vaux.

June I6. Spain's official declaration of grievances presented to the British ministry; Spain institutes siege of Gibraltar. D'Estaing captures St. Vincent.

June 17. John Adams returns to America on Le Sensible.

June 25. Bancroft reports to Vergennes on the condition of Ireland.

July 1. Lafayette arrives at Le Havre.

July 4. D'Estaing captures Grenada.

July I 6. Wayne retakes Stony Point.

July 18. Lafayette submits memoir to French ministry on sending an expeditionary force to America. 
July 23. Juncture of Spanish and French fleets off Cape Finisterre.

ca. August 15. Combined fleet enters the Channel.

September 14. Combined fleet puts in to Brest.

September 23. Bonhomme Richard-Serapis engagement.

October 9. American and French defeat at Savannah.

October 25. British evacuate Rhode Island.

November. Expedition against England abandoned.

November 9. Córdoba sails from Brest.

December 24. Birth of Lafayette's son, George-Washington.

December 26. British fleet and troops under Clinton sail from New York for Charleston, South Carolina. 1780

January 8-16. Rodney captures Spanish convoy and Spanish blockading squadron.

January 25. Lafayette proposes an expeditionary corps be sent to America.

January-February. Negotiates for arms and munitions for Americans and presents his recommendations concerning an expeditionary force.

February 9. John Adams arrives in Paris.

ca. February 21-28. Lafayette meets with the ministry at Versailles concerning an expeditionary force.

February 28? Takes leave of the king in his American uniform.

February 29. Catherine II issues Declaration of Armed Neutrality.

March 5. Lafayette receives his instructions.

March 9. Arrives at Rochefort.

March 13. Sails for America on L'Hermione.

March 17. L'Hermione returns to Rochefort with broken main yard.

March 20. Sails again.

April 27. Arrives in Boston harbor.

May 2. French fleet and expeditionary force under Ternay and Rochambeau sail from Brest.

September 25-28. Lafayette with Washington at West Point; discovers Arnold's treason.

September 29. Appointed to a board of general officers to try Major André. 1781

February 22. Leads a detachment to Virginia to counter British forces under Arnold.

April 22-October 19. Commands Continental forces during the Virginia campaign against Cornwallis.

July 6. Battle of Green Spring against Cornwallis.

July 27. Cornwallis decides to occupy Yorktown; Lafayette besieges him.

September 2. De Grasse's fleet arrives at Yorktown; French marines placed under Lafayette's command.

September 14. Arrival of American and French forces under Washington and Rochambeau.

October 14. Capture of Redoubt No. 10 by troops under Lafayette's command.

October 19. Cornwallis surrenders. 
December 23. Departs for France on board the Alliance. 1782

September 17. Birth of daughter Virginie.

October 24. Accepts position of quartermaster general of Franco-Spanish expeditionary force mobilizing at Cadiz. 1783

January 2o. Preliminary peace, hostilities officially ended.

March. Lafayette becomes a maréchal de camp in the French army. 1784

August 4-December 21. American tour. 1786

Works for French trade concessions for the United States as a member of the "American Committee."

August. Buys plantation in Cayenne for experiment in slave emancipation. 1787

February 22-May 25. Attends Assembly of Notables.

May 24. Calls for toleration of the Protestants and reform of the criminal law. 1788

November 6-December 12. Attends Second Assembly of Notables; supports doubling of the Third Estate. 1789

March 26. Elected deputy to the Estates General from Auvergne.

June 27. Joins with the Third Estate, which had constituted itself as the National Assembly.

July 11. Presents draft for the Declaration of the Rights of Man and the Citizen.

July 13. Chosen vice-president of the National Assembly.

July 14 . Fall of the Bastille.

July 15. Lafayette proclaimed commandant of the Paris National Guard.

October 5-6. Leads Paris National Guard to Versailles; brings the king to Paris.

1790

June 19. Supports decree abolishing titles of nobility.

July 14. Presides at Federation ceremony of the National Guard.

1791

June 21 . Flight of the king to Varennes.

July 17. Demonstration at the Champ de Mars dispersed by the National Guard.

October 8. Lafayette resigns as commandant of the Paris National Guard. 1792

ca. January 1. Takes command of the Army of the Center at Metz.

May-August. Commands the Army of the Left.

August 10. Arrest of the king.

August 19. Lafayette impeached by the Convention. Emigrates and is captured by the Austrians.

September 18, 1792-September 19, 1 797. Imprisoned at Wesel, Magdeburg, Neisse, and Olmütz. 
1795

October 24. Joined by wife and daughters in prison at Olmütz.

1797

September 19. Released from prison under the terms of the Treaty of Campo-Formio.

November. Moves to Lemkühlen, Holstein.

1799

ca. January. Moves to Vianen, Holland.

November 9-Io( 8 Brumaire). Establishment of the Consulate. 1800

January. Lafayette establishes residence at La Grange. 1807

December 24. Death of his wife, Adrienne.

1815

Begins first of several terms in the Chamber of Deputies.

June I 8. Battle of Waterloo.

June 22. Lafayette insists on Bonaparte's abdication.

1824

August 16. Arrives in New York for American tour.

1825

September 9. Sails for France.

1830

July 28-3o. Plays leading role in Revolution of 1830 .

August 16-December 26. Commandant of National Guard of the Realm. 1834

May 2o. Death in Paris. 